\title{
sciendo
}

CIVIL AND ENVIRONMENTAL ENGINEERING REPORTS

E- ISSN 2450-8594

CEER 2020; 30 (2): 0092-0104

DOI: $10.2478 /$ ceer-2020-0022

Original Research Article

\section{TREATMENT AND UTILIZATION OF THE CONCENTRATE FROM MEMBRANE SEPARATION PROCESSES OF LANDFILL LEACHATES}

\author{
Rafał NOWAK, Maria WŁODARCZYK - MAKUŁA ${ }^{1}$ \\ Czestochowa University of Technology, Department of Environmental Engineering \\ Czestochowa, Poland
}

\begin{abstract}
The purpose of the paper was to assess the effectiveness of selected physico-chemical processes to improve the quality of retentates/concentrates obtained during the treatment of landfill leachates using membrane separation. Among the physico-chemical methods, Advanced Oxidation Process (AOP) and electrocoagulation were analysed. Landfill leachate resulting from the infiltration of waste mass by atmospheric precipitation as well as the dissolution and leaching of waste components are most often subjected to membrane separation. Permeate is usually discharged to the receiver, while the concentrate is recirculated and sprinkled on a waste pile. However, such action is only the retention of impurities in the body of the landfill and has an impact on the chemistry of raw leachates. Due to the very high concentrations of organic and inorganic compounds identified in the retentate, it is necessary to treat it, which will effectively reduce the amount of impurities in the leachate. Economic use seems to be another solution. An example would be growing energy crops but such application requires additional research.
\end{abstract}

Keywords: landfill leachate, retentate, membrane processes, electrocoagulation, AOP

\footnotetext{
${ }^{1}$ Corresponding author: Czestochowa University o f Technology, 42 - 200 Czestochowa, 69 Dabrowskiego Str., +48 3250919, email: mwm@is.pcz.czest.pl
} 


\section{INTRODUCTION}

As is known, landfill leachates are formed as a result of infiltration of rainwater through a layer of deposited waste and leaching and dissolution of waste components. The chemical composition of these leachates vary and depend on the type of waste and the duration of the landfill.

Landfill leachates are usually drained through a drainage system and collected in storage reservoirs called leachate reservoirs. In practice, they are often open earth reservoirs, but properly protected against leachate infiltration into the ground and penetration of components into the soil and water environment. From these averaging reservoirs, the leachate is usually directed to purification installations consisting of several unit processes. Subsequently, pre-treated and/or purified leachates can be discharged into a surface water receiver. Physical, chemical and biological processes are used in effluent treatment installations. Among the physicochemicals processes the following can be distinguished [17, 26, 27]:

- chemical neutralization and precipitation,

- coagulation with flocculation,

- filtration,

- ammonia stripping with air,

- pressure membrane processes.

The choice of processes depends on the qualitative composition of the leachate and the requirements of the water permit allowing the discharge of purified leachate to the environment. Pressure membrane processes such as ultrafiltration, nanofiltration and reverse osmosis (RO) are most widely used $[1,19,20,28,38,42]$. Membrane modules are equipped with purification installations located at large landfills for many cities in Poland (e.g. Częstochowa). The basic process is RO reverse osmosis. The permeate can usually be drained to the receiver, which is allowed by the water law permit [14]. On the other hand, the retentate, constituting $20-25 \%$ of the leachate directed for treatment, is highly loaded with impurities retained as a result of the separation process $[16,35,36]$. In operated landfills, retentate is usually recirculated and spread on a pile of waste. This solution increases the concentration of impurities in raw leachate. Research by Tałałaj and Biedki showed that recirculation of the concentrate to the body of the landfill causes an increase in the concentration of COD, BOD and ammonium nitrogen, and changes in the leachate quality may affect the efficiency of raw leachate treatment in the RO installation $[38,39]$. Thus, although recirculation of the concentrate to the landfill can accelerate the decomposition of waste components, dissolution and leaching, it does not comprehensively solve the problem. Drains from membrane cleaning are an additional waste water stream. 
Due to the high concentration of organic and inorganic compounds, including toxic ones, further processing of the concentrate is necessary, consisting of improving the quality and/or recovery of useful ingredients. The aim of the study was to assess the effectiveness of selected physico-chemical methods that can be used to neutralize the concentrate obtained from membrane separation of landfill leachates and to identify the possibility of using the concentrate for economic purposes.

\section{CHARACTERISTICS OF THE CONCENTRATE FROM MEMBRANE SEPARATION PROCESSES OF LANDFILL LEACHATES}

In the literature, most of the works concern the characteristics of raw landfill leachates and permeate $[2,5,10,17,33,34,37,42]$, however, little information is available about the concentrated concentrate. Considering the large diversity of chemical compounds found in raw leachates and the high values of retention coefficients on membranes, it can be stated that most of the impurities will be retained in the concentrate. For example, removal of organic compounds is estimated to reach $99 \%$. It should be emphasized that in the waste mixture there are continuous transformations of organic compounds that lead to the formation of macromolecular compounds, mainly humic substances. Studies have shown that the proportion of humic compounds in the total amount of soluble organic carbon can reach $60 \%$. It is also observed that the molar masses of these compounds and the share of individual fractions vary (from several hundred to tens of thousands of Da), which depends on the age of the landfill. Chemical chemistry of landfill leachate has repeatedly confirmed that leachates also have toxic organic compounds such as: biologically active ingredients in plant protection products, polycyclic aromatic hydrocarbons (PAHs), halogenated organic derivatives or petroleum hydrocarbons (BTX) and benzenesulfonates (LAS), phthalates (DEHP) and many other connections [12, 16, 31]. Determination of individual compounds in leachates is random and usually the content of organic compounds is expressed in general COD and BOD indicators, and the proportion between these indicators informs about the biochemical transformations of these compounds in waste $[16,25]$. RO installations also have high inorganic compound retention rates. An exemplary decrease in the value of inorganic compounds concentration recorded in the Tałałaj study was in the range of 83-97\% [39]. Therefore, taking into account the high degree of separation both organic and inorganic compounds on membranes, they are present in high concentrations in concentrate. Exemplary values of concentrate quality indicators from the reverse osmosis process are presented in Table 1, while biogenic and other components - in Table 2. 
Table 1. Average values of selected quality indicators of the concentrate from landfill leachates treatment by reverse osmosis $[9,15,30,32]$

\begin{tabular}{|l|c|c|c|c|c|}
\hline \multirow{2}{*}{\multicolumn{1}{|c|}{ Indicator }} & \multirow{2}{*}{ Unit } & \multicolumn{4}{c|}{ References } \\
\cline { 3 - 6 } & & {$[9]$} & {$[15]$} & {$[30]$} & {$[32]$} \\
\hline $\mathrm{pH}$ & - & 8.2 & - & 7.2 & 7.5 \\
\hline Conductivity & $\mathrm{mS} / \mathrm{cm}$ & 31.3 & - & 51.4 & 27.8 \\
\hline COD & $\mathrm{mg} / \mathrm{dm}^{3}$ & 9700 & 26771 & 7450 & 2198 \\
\hline BOD $_{5}$ & $\mathrm{mg} / \mathrm{dm}^{3}$ & 3750 & 3750 & 365 & - \\
\hline Total organic carbon & $\mathrm{mg} / \mathrm{dm}^{3}$ & - & - & 1820 & 719 \\
\hline Ammonium nitrogen & $\mathrm{mg} / \mathrm{dm}^{3}$ & 3580 & - & 1580 & 2388 \\
\hline Total nitrogen & $\mathrm{mg} / \mathrm{dm}^{3}$ & - & - & 4575 & 2571 \\
\hline Sulphur & $\mathrm{mg} / \mathrm{dm}^{3}$ & 2657 & - & 453 & - \\
\hline Chloride & $\mathrm{mg} / \mathrm{dm}^{3}$ & 3530 & - & 6430 & 1823 \\
\hline Iron & $\mathrm{mg} / \mathrm{dm}^{3}$ & 9.0 & - & 2.89 & - \\
\hline
\end{tabular}

Table 2. Concentrations of selected elements identified in the concentrate from the treatment of landfill leachates by reverse osmosis $\left[\mathrm{mg} / \mathrm{dm}^{3}\right][30]$

\begin{tabular}{|l|c|l|c|l|c|}
\hline \multicolumn{1}{|c|}{ Indicator } & Value & Indicator & Value & \multicolumn{1}{|c|}{ Indicator } & Value \\
\hline $\begin{array}{l}\text { General } \\
\text { phosphorus }\end{array}$ & 23 & $\begin{array}{l}\text { Nitrate } \\
\text { nitrogen V }\end{array}$ & 5,620 & $\begin{array}{l}\text { Nitrate } \\
\text { nitrogen III }\end{array}$ & 5,388 \\
\hline Calcium & 532 & Aluminium & 1,450 & Arsenic & 0.52 \\
\hline Magnesium & 498 & Zinc & 0.8 & Nickel & 0.37 \\
\hline Potassium & 3,783 & Manganese & 1.17 & Chrome & 0.2 \\
\hline Sodium & 3,914 & Copper & 0.14 & Lead & 0.13 \\
\hline
\end{tabular}

\section{TREATMENT OF THE CONCENTRATE FROM THE MEMBRANE SEPARATION PROCESS OF LANDFILL LEACHATES}

Due to the fact that membrane filtration processes do not degrade pollutants but only separate them, the separated concentrate contains most of the components separated from wastewater and should be neutralized or purified. The following methods of concentrate treatment are listed in the literature $[6,32,37]$ :

- recirculation,

- incineration and solidification with other materials,

- evaporation,

- granulation,

- purification to remove impurities,

- utilization of the landfill in the block. 
The technology of solidifying concentrates with materials such as fly ash or sludge from sewage treatment plants and recirculation to the landfill can be used to improve the efficiency of biochemical degradation and accelerate the immobilization of mobile components. However, due to low costs, the latter option is currently the most widely used. Proponents of this solution indicate that the landfill can be compared to a bioreactor in which biogas is produced. This requires appropriate conditions with respect to humidity and air in the landfill to accelerate biochemical processes and shorten the time of biochemical transformation as well as migration of nutrients and microorganisms in the landfill. In addition to recycling to the landfill, the concentrate can be subjected to evaporation and the resulting residue directed for storage. The concentrate granulation technology is also used [37]. It is an energy-consuming technology consisting of drying concentrate in hydrocyclone devices with steam heating and a distillate cooler. Concentrated leachates are directed to a special dryer, where dry granules are formed. Post-process sewage, created after drying, is discharged into the leachate reservoir, while the resulting granulate - deposited in a landfill. The disadvantage of the process is the reintroduction of impurities to the waste mass. In the described cases, the problem is the increase in the concentration of toxic compounds in the body of the landfill, which are not biodegradable and accumulate in the system. The literature presents works on the impact of concentrate recirculation on the quality of leachates and indicates an increase in the value of COD, ammonium nitrogen and an increase in salinity in raw landfill leachates. As a consequence, this negatively affects the efficiency of the RO installation itself and reduces the value of impurity retention coefficients [6, 24]. Another solution to the concentrate problem is their disposal or economic use. For the disposal or further treatment of concentrates from the process of membrane separation of leachates, advanced chemical oxidation, electrocoagulation or anodic oxidation processes can be used. The effectiveness of these methods depends on the properties of the compounds removed and the conditions of the process.

\subsection{ADVANCED OXIDATION PROCESSES}

Advanced chemical oxidation (AOP) processes include chemical, photochemical, catalytic and electrochemical oxidation, and combinations thereof. The most commonly used processes include the use of ozone, hydrogen peroxide or Fenton's reagent supported by UV radiation. These processes can be supported by ultrasound and/or hydrodynamic cavitation and electric current. Radicals, mainly hydroxyl $\mathrm{OH} \bullet$ play the most important role in these processes. They are characterized by high oxidation potential and therefore difficult to decompose organic compounds can be completely mineralized or transformed into biodegradable compounds. Also complex hydrophobic aromatic and/or 
aliphatic compounds are converted to hydrophilic compounds. Virapan et al. [40] studied the distribution of organic pollutants from the retentate resulting from the treatment of pharmaceutical wastes (pharmaceuthics Phs) and personal care products (personal care products $\mathrm{PCP}$ ). During chemical oxidation, the efficiency of removing organic impurities from the retentate ranged from 40 to $50 \%$. Chemical oxidation support through UV exposure resulted in a significant increase in the degree of removal of impurities from 80 to $100 \%$ [40]. KocJurczyk and Jurczyk used Fenton's reagent to neutralize concentrate purification after reverse osmosis from leachates [15]. The effect of $\mathrm{pH}$ on the removal efficiency of organic and humic compounds was analyzed. As other authors also indicate $[4,8,15]$, the best purification effects are obtained during oxidation in an acidic environment $(\mathrm{pH} 3)$. The efficiency of organic compounds decomposition can reach $80,90 \%$ for $\mathrm{COD}$ and $\mathrm{BOD}_{5}$ respectively. At the same time, there is an increase in the value of the ratio of these indicators confirming the increase in biodegradability of the obtained product. The authors confirmed that the only operational problem with the use of Fenton's reagent is the need to acidify the reaction environment [15]. Comparative studies of the classical Fenton process and the electro-Fenton process were conducted by Fernandes and others [9]. As in the studies described above, it has been shown that higher efficacy is achieved after acidification of the retentate $(\mathrm{pH} 3)$. It has also been shown that the efficiency of removing organic compounds is directly proportional to the increase in current flowing through the electrodes. Process support had an impact on the increase in the amount of hydroxyl radicals, which determine the oxidation of organic compounds. However, the decrease in COD was not greater than $50 \%$. Comparative studies of selected AOP methods, including ozone, UV radiation, hydrogen peroxide, electrocoagulation and electrochemical oxidation were conducted by Gautam et al. [10]. The research was carried out with the use of a synthetic concentrate that may be formed during the treatment of leachate from a hazardous waste landfill. In this concentrate in high concentrations there were refractive organic (chloroorganic) compounds, ammonium nitrogen, selected heavy metals and inorganic salts. Studies have shown that when using the above processes, the COD value decrease did not exceed $60 \%$. Similar comparative studies of the effects of UV radiation, the electro-Fenton process and photo-electro-Fenton process on the removal of impurities were conducted by Asaitharnbi et al. [2]. The dependence of the removal of organic compounds expressed by the COD indicator on the initial concentration, $\mathrm{pH}$ value, colour, hydrogen peroxide concentration, electricity consumption and UV dose was determined. The test results showed that under the most favourable process conditions of the hybrid photo-electroFenton process, removal of organic compounds at the level of $97 \%$ and complete colour removal was achieved [2]. Photochemical catalytic oxidation of 
organic compounds in reverse osmosis concentrate has been studied by Westerhoff et al. [41]. The combination of UV radiation in the presence of a catalyst, which was titanium dioxide $\left(\mathrm{UV} / \mathrm{TiO}_{2}\right)$, allowed to obtain a high degree of removal of organic compounds. The inclusion of filtration in AOP has contributed to a higher efficiency in removing organic compounds at lower UV doses. At the highest dose of UV radiation $\left(10 \mathrm{kWh} / \mathrm{m}^{3}\right)$, the concentration of dissolved organic carbon in the RO retentate decreased by $80 \%$, while in the case of the integrated process (with filtration) it reached $91 \%$ [41].

\subsection{ELECTROCOAGULATION AND ANODE OXIDATION}

Electrocoagulation (EC) $[5,7,13,18,23,34]$ is an effective method of purifying leachates from landfills, allowing the removal of dissolved and undissolved impurities without introducing additional reagents. This process can also be used at a later stage of purification of both permeate and concentrate. Studies by Gautam and others have shown that the use of EC allows the removal of organic compounds determined in 50\% while reducing the content of heavy metal ions to $90 \%$ [10].

Malinovic et al. conducted research on concentrate disposal from the RO process in the electrocoagulation process [21, 22]. The experiment was carried out using anodes made of iron or aluminium, in a batch electrochemical reactor. Changes in the concentration of dissolved compounds (determined as a dry residue) and turbidity were monitored. The research results showed that with the use of the iron anode, the efficiency of removing dissolved compounds and turbidity was 96 and $22 \%$, respectively, while with the aluminium anode - 17 and $11 \%$ [21, 22].

Fernandes et al. Also investigated the possibility of using EC to neutralize reverse osmosis retentate [9]. A comparative experiment using electrocoagulation and anode oxidation (AO) and the Fenton process were carried out in parallel. Tests were carried out in periodically powered reactors. During electrocoagulation, stainless steel electrodes were used at variable currents. The removal of organic compounds expressed as the COD index depended on the current and ranged from 32 to $65 \%$. Anode oxidation was carried out under the same conditions, but using a two-cathode system between which the anode was mounted. The cathodes were stainless steel plates and the anode was a bipolar electrode. The efficiency of removing organic compounds designated as COD in the $\mathrm{AO}$ process depended on the $\mathrm{pH}$ value of the reaction medium and the intensity of the current. With the decrease of the $\mathrm{pH}$ value and the increase of the current intensity, the oxidation efficiency increased and reached the maximum value of $74 \%$ [9].

A relatively new solution is the patented technology with the use of electrode concentrator (EDC) [3, 11]. In this reactor, a graphite anode was designed, while 
a cathode was made of stainless steel. In addition, cationic and anionic membranes were placed alternately in the reactor at a distance of $1.5 \mathrm{~mm}$, obtaining desalination and concentration chambers. Introduction of sodium chloride solution into the electrode chamber and application of voltage causes ion migration through ion exchange membranes and concentrate concentration. The research was carried out using retentate after reverse osmosis, which is formed during leachates treatment. The removal efficiency of organic compounds expressed as COD index reached $70 \%$. Moreover, ammonium nitrogen concentration was reduced by $45 \%$, total iron - $97 \%$, total hardness - by $42 \%$ and colours by $74 \%$. The disadvantage of this technology is the increase in chloride concentration by about $66 \%$ and the formation of deposits. However, the brine obtained after the process can be electrochemically transformed into sodium hypochlorite and reused for decontaminating landfill leachates $[3,11]$.

\section{USE OF CONCENTRATE}

As already mentioned, qualitative studies of the concentrate from membrane separation are few. Based on the available data, it can be concluded that the qualitative composition is diverse, which makes it difficult to develop the conditions for use. The high concentration of organic compounds, nitrogen compounds and the presence of potassium in leachates mean that they can be used to intensify the cultivation of industrial plants. However, it should be taken into account that on the one hand the concentrate contains fertilizer components, and on the other - toxic compounds that can accumulate in soil and organisms. Thus, such management of concentrates creates the danger of leaching of toxic components and migration to soils and the aquatic environment. Initial research in this area was conducted by the Co-author [29]. The experiment used diluted landfill leachates, which was used to intensify the cultivation of energy willow (Salix viminalis). In the conducted experiment, in determined conditions, an increase in energy willow growth was noted to $70 \%$. From a logistical point of view, when industrial cultivation is significantly distant from the municipal waste landfill, it seems more convenient to use a concentrated concentrate for this purpose after RO. Another solution would be to establish a willow plantation near the landfill, which could further enhance the landscape.

\section{CONCLUSION}

Reverse osmosis modules are often used in landfill leachates treatment installations, from which a concentrate of various qualities is discharged. The volume of this concentrate accounts for $25 \%$ of the stream directed for purification, so this is a significant amount. An additional source of sewage is 
the chemical cleaning of membranes, which is necessary due to the varying qualitatively leachates and high membrane separation capabilities, which promotes phenomena such as fouling or scaling. The problem with concentrate and sewage generated after membrane cleaning processes is not entirely solved. Usually these streams return to the waste mass. Due to the disadvantages of concentrate recirculation to the body of the landfill, consisting in enrichment of waste with concentrated components previously separated from leachates, it is necessary to search for other solutions. Among the processes of neutralizing retentate, in-depth oxidation and electrocoagulation are the most effective. AOP methods allow for effective degradation of organic compounds and increase of biodegradability of residues. However, it requires the use of chemical reagents and possibly UV power supply to the system. The electrocoagulation process is also associated with energy demand. The comparison of processes in economic terms is not easy because it depends on the concentration and type of pollution as well as the type and technological parameters of the disposal process. In addition, energy consumption, and hence the cost of treatment, increases as the quality requirements of the disposal product increase. Economic use seems to be another solution. An example would be growing energy crops. However, such application requires additional research not only in terms of assessing the impact on the growth of plant mass but also in terms of assessing the impact on soil and water environment".

Acknowledgements: The scientific research was funded by the statute subvention of Czestochowa University of Technology, Faculty of Infrastructure and Environment"

\section{REFERENCES}

1. Ahmed, FN and Lan, CQ 2012. Treatment of landfill leachate using membrane bioreactors: a review. Desalination 287, 41-54.

2. Asaitharnbi, P, Govindarajan, R, Yesue, MB and Alemayehu, E 2020. Removal of color, COD and determination of power consumption from landfill leachate wastewater using an electrochemical advanced oxidation processes, Separation and Purification Technology 233, 115935, $<$ https://doi.org/10.1016/j.seppur.2019.115935>.

3. Balakina, MN 2015. Electrolysis in complex processing of leachate of solid waste landfills, Journal of Water Chemistry and Technology 37, 179-184.

4. Barbusiński, K 2013. Advanced oxidation in the treatment processes of selected industrial wastewater (Zaawansowane utlenianie $w$ procesach oczyszczania wybranych ścieków przemystowych). Gliwice: Wydawnictwo Politechniki Śląskiej. 
5. Cabeza, A, Urtiaga, AM and Ortiz, I 2007. Electrochemical treatment of landfill leachates using a boron-doped diamond anode, Industrial \& Engineering Chemistry Research 46, 1439-1446.

6. Calabrò, PS, Gentili, E, Meoni, C, Orsi, S and Komilis D 2018. Effect of the recirculation of a reverse osmosis concentrate on leachate generation: A case study in an Italian landfill. Waste Management 76, 643-651.

7. Chen, G 2004. Electrochemical technologies in wastewater treatment, Separation and Purification Technology 38, 11-41.

8. Ebrahiem, EE, Al-Maghrabi, MN and Mobarki, AR 2017. Removal of organic pollutants from industrial wastewater by applying photo-Fenton oxidation technology, Arabian Journal of Chemistry 10, 1674-1679.

9. Fernandes, A, Chamem, O, Pacheco, MJ, Ciríaco, L, Zairi, M and Lopes, A 2019. Performance of Electrochemical Processes in the Treatment of Reverse Osmosis Concentrates of Sanitary Landfill Leachate, Molecules 24, $2905,<$ https://doi.org/10.3390/molecules24162905>.

10. Gautam, P, Kumar, S and Lokhandwala S 2019. Advanced oxidation processes for treatment of leachate from hazardous waste landfill: A critical review, Journal of Cleaner Production 237, 117639, $<$ https://doi.org/10.1016/j.jclepro.2019.117639>.

11. Goncharuk, VV, Kucheruk, DD and Balakina, MM 2011. Patent of Ukraine 95026, IPC 6 B01/D 61/4, C02F 1/469, Byull. no. 12.

12. Grosser, A, Jelonek, P and Neczaj, E 2015. Trends in landfill leachate treatment (Trendy w oczyszczaniu odcieków składowiskowych), In: Wiśniewski, J, Kutyłowska, $\mathrm{M}$ and Trusz-Zdybek, A (ed) Interdyscyplinarne zagadnienia $w$ inżynierii $i$ ochronie środowiska 5, Oficyna Wydawnicza Politechniki Wrocławskiej, Wrocław, Poland, 95-124.

13. Ilhan, F, Kurt, U, Apaydin, O and Gonullu, MT 2008. Treatment of leachate by electrocoagulation using aluminum and iron electrodes. Journal of Hazardous Materials 154, 381-389.

14. Integrated permit (Pozwolenie zintegrowane), Decyzja Marszałka Województwa Śląskiego nr 1381/OS/2016 z dnia 10.06.2016 r.

15. Koc-Jurczyk, J and Jurczyk, Ł 2019. Influence of $\mathrm{pH}$ in AOP on Humic Compounds Removal from Municipal Landfill Leachate Concentrate after Reverse Osmosis, Journal of Ecological Engineering 20, 161-168.

16. Kulikowska, D 2009. Characterization of organics and methods treatment of leachate from stabilized municipal landfills (Charakterystyka oraz metody usuwania zanieczyszczeń organicznych $\mathrm{z}$ odcieków pochodzących $\mathrm{z}$ ustabilizowanych składowisk odpadów komunalnych), Ecological Chemistry and Engineering S 16(3), 389-401. 
17. Kurniawan, TA, Lo, WH and Chan, GYS 2006. Physico-chemical treatments for removal of recalcitrant contaminants from landfill leachate, Journal of Hazardous Materials 129, 80-100.

18. Labiadh, L et al. 2016. Electrochemical treatment of concentrate from reverse osmosis of sanitary landfill leachate. Journal of Environmental Management 181, 515-521.

19. Leachate from landfills (Odcieki ze składowisk odpadów) <www.awas.pl/wp-content/uploads/2013/10/uzdatnianie_odcieki.pdf $>$ (12.05.2020 r.).

20. Liu, Y, Li, X, Wang, B and Liu, S 2008. Performance of landfill leachate treatment system with disc-tube reverse osmosis unit, Frontiers of Environmental Science \& Engineering in China 2, 24-31.

21. Malinovic, B, Djuricic, T and Pavlović, M 2017. Treatment of leachate by electrocoagulation using aluminium electrode. Proceedings of XIX YUCORR International Conference, Tara, Serbia.

22. Malinovic, B, Djuricic, T, Bjelić, D and Markic, D 2017. Treatment of reverse osmosis retentate of landfill leachate by electrocoagulation, Proceedings of 6th Regional Symposium on Electrochemistry of South-East Europe (6th RSE-SEE), Balatonkenese, Hungary.

23. Mohajeri, S, Hamidi, A, Isa, M and Zahed, M 2019. Landfill leachate treatment through electro-Fenton oxidation. Pollution 5, 199-209.

24. Morello, L, Cossu, R, Raga, R, Pivato, A and Lavagnolo MC 2016. Recirculation of reverse osmosis concentrate in lab-scale anaerobic and aerobic landfill simulation reactors. Waste Management 56, 262-270.

25. Myszograj, S 2013. Effects of the solubilisation of the COD of municipal waste in thermal disintegration, Archives of Environmental Protection 39, 57-67.

26. Nowak, R, Janosz-Rajczyk, M and Dąbrowska, L 2004. Removal of ammonium nitrogen and organic compounds from landfill leachate in the fluidized ashes layer (Usuwanie azotu amonowego i związów organicznych $z$ odcieków składowiskowych $w$ warstwie popiołów fluidalnych), Proceedings of Mikrozanieczyszczenia w środowisku człowieka, Częstochowa-Ustroń, Polska, 319-323.

27. Nowak, R and Janosz-Rajczyk, M 2005. Removal of ammonium nitrogen from leachate using rotating contactors (Usuwanie azotu amonowego $z$ odcieków składowiskowych na tarczowych złożach biologicznych), Proceedings of Mikrozanieczyszczenia w środowisku człowieka, Częstochowa, Poland, 147-149.

28. Nowak, R, Włodarczyk-Makuła, M, Wiśniowska, E and Grabczak, K 2016. The Comparison of the Effectiveness of Pre-treatment Processes of Landfill Leachate. Annual set the Environment Protection 18, 122-133. 
29. Nowak, R and Kopeć, B 2018. Research on the possibility of using landfill leachate to intensify the cultivation of energy willow (Badania nad możliwością wykorzystania odcieków składowiskowych do intensyfikacji uprawy wierzby energetycznej), In: Dąbrowska, L and Włodarczyk-Makuła M (ed) Mikrozanieczyszczenia $w$ ściekach, odpadach $i$ środowisku, Wydawnictwo Politechniki Częstochowskiej, 268-276.

30. Qi, X, Zhang, C and Zhang Y 2015. Treatment of Landfill Leachate RO Concentrate by VMD, Proceedings of International Conference on Circuits and Systems (CAS 2015), Paris, France, 13-17.

31. Sadecka, Z, Myszograj, S, Sieciechowicz, A, Płuciennik-Koropczuk, E and Włodarczyk-Makuła, M 2016. Impact of selected insecticides on the anaerobic stabilization of municipal sewage sludge, Desalination and Water Treatment 57 (3), 1213-1222.

32. Scantamburlo, E 2015. Reinjection of leachate reverse osmosis concentrate in the landfill body, Master thesis. Padova: University of Padova.

33. Singh, SK and Tang, WZ 2013. Statistical analysis of optimum Fenton oxidation conditions for landfill leachate treatment, Waste Management 33, 81-88.

34. Sivakumar, D, Rajaganapathy, J, Anand, R, Mariavensa, S and Preethi, S 2015. TOC and COD removal from municipal solid waste leachate using electrocoagulation method, Journal of Chemical and Pharmaceutical Sciences 8, 745-749.

35. Smol, M and Włodarczyk-Makuła, M 2017. Effectiveness in the Removal of Organic Compounds from Municipal Landfill Leachate in Integrated Membrane Systems: Coagulation - NF/RO. Polycyclic Aromatic Compounds 37(5), 456-474.

36. Smol, M and Włodarczyk-Makuła, M 2017. The Effectiveness in the Removal of PAHs from Aqueous Solutions in Physical and Chemical Processes: A Review. Polycyclic Aromatic Compounds 37(4), 292-313.

37. Stepniak, S 2008. New techniques of cleaning leachate from municipal landfills. Membrane methods: ultrafiltration, nanofiltration and reverse osmosis (Nowe techniki oczyszczania odcieków wodnych z wysypisk komunalnych. Metody membranowe: ultrafiltracji, nanofiltracji i odwróconej osmozy), Rynek Instalacyjny 10, 119-122.

38. Tałałaj, IA 2015. Removal of organic and inorganic compounds from landfill leachate using reverse osmosis, International Journal of Environmental Science and Technology 12, 2791-2800.

39. Tałałaj, IA and Biedka, P 2015. Impact of concentrated leachate recirculation on effectiveness of leachate treatment by reverse osmosis. Ecological Engineering 85, 185-192. 
40. Virapan, S, Saravanane, R and Murugaiyanb, V 2017. Treatment of Reverse Osmosis Reject Water from Industries, International Journal of Applied Environmental Sciences 12, 489-503.

41. Westerhoff, P, Moon, H, Minakata, D and Crittenden J 2009. Oxidation of organics in retentates from reverse osmosis wastewater reuse facilities, Water Research 43, 3992-3998.

42. Zhang, SJ, Peng, YZ, Wang, SY, Zheng, SW and Guo, J 2007. Organic matter and concentrated nitrogen removal by shortcut nitrification and denitrification from mature municipal landfill leachate, Journal of Environmental Sciences 19, 647-651.

Editor received the manuscript: 01.06.2020 